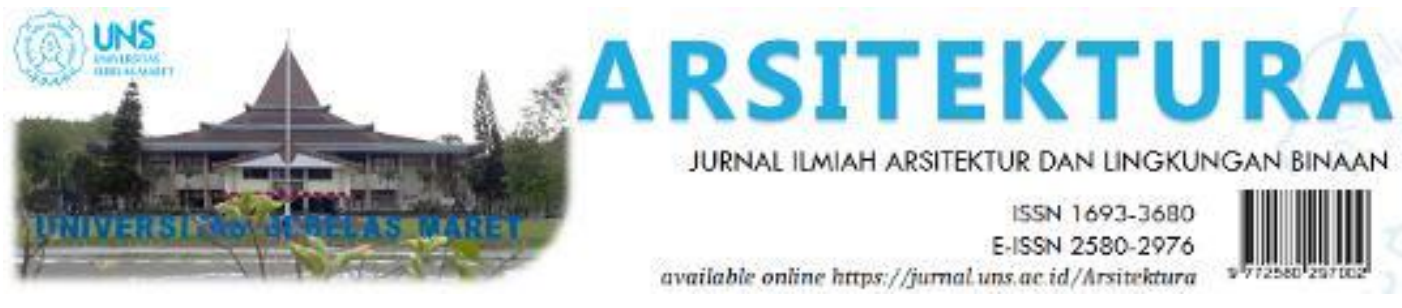

Volume 18 Issue 1 April 2020, pages:84-93

\title{
Karakter Bentuk Hunian Suku Rejang Di Daerah Rawan Gempa (Studi Kasus: Desa Gunung Alam, Kabupaten Lebong)
}

\section{Characteristics of form of Rejang Clan Dwelling in Earthquake Prone Areas (Case Study: Gunung Alam Village, Lebong Regency)}

\author{
Atik Prihatiningrum $^{1 *}$, Panji Anom Ramawangsa ${ }^{2}$, Samsul Bahri $^{3}$ \\ Architecture Department, Faculty of Engineering, University of Bengkulu ${ }^{1 *}$ \\ Email: atikprihatiningrum@gmail.com* \\ Architecture Department, Faculty of Engineering, University of Bengkulu ${ }^{2}$ \\ Architecture Department, Faculty of Engineering, University of Bengkulu ${ }^{3}$
}

DOI: https://doi.org/10.20961/arst.v18i1.40786

Received: March 12, 2020 Revised : April 13,2020 Accepted: April 13,2020 Available online:April 30, 2020

\begin{abstract}
The knowledge of building housing by the Rejang clan in Gunung Alam Village by trial and error using local materials as well as a simple way of reflecting the uniqueness of the form of shelter in the Rejang clan community residing in mountainous rural areas. The focus of this research is to identify the relationship between the form of shelter and the realization of anticipation of occupancy as its role as adaptive shelter in earthquake prone areas. This research is a qualitative descriptive study describing the form of occupancy of the Rejang Clan by exploring the configuration of the building and its structural system to understand the form of occupancy of the Rejang Clan as an adaptive building in earthquake prone areas. The adaptability of the Rejang clan as a shelter in earthquake-prone areas has been implemented through the form of houses on stilts which have a ratio of widths and lengths of buildings 1: 2 with symmetrical and simple spatial arrangements. Ratio of balanced heights in each structure. However, the use of nails has been found in homes and the addition of space that forms a new mass behind the original mass of housing with brick material becomes a risk in the event of an earthquake in the future. Even so, the Rejang Clan occupancy in Gunung Alam Village is still strong to be inhabited by the Rejang Clan and is adaptive in responding to earthquake shocks.
\end{abstract}

Keywords: Character, Dwelling, Earthquake, Form, Rejang Clan

\section{PENDAHULUAN}

Pada masyarakat Suku Rejang yang berada di kawasan rural, pengetahuan membangun hunian dilakukan dengan mencoba-coba (trial and error) menggunakan bahan lokal dan cara yang sederhana karena hanya berdasarkan pengetahuan seadanya yang dimiliki oleh Suku Rejang saat itu. Trial and error ini merupakan bentuk evaluasi dan antisipasi pada perubahan tingkat ekonomi, tingkat pendidikan, dan keyakinan/agama penghuni tetapi juga pada perubahan tatanan sosial, budaya, iklim, dan alam yang menghasilkan perubahan bentuk hunian dari masa ke masa. Bentuk dari hunian pada setiap daerah memiliki kekhasan berbeda-beda karena penyelesaian struktur dan teknik konstruksinya akan berhubungan dengan kondisi ekternal. 
Kabupaten Lebong merupakan daerah yang terletak berbatasan dengan bukit barisan dimana pegunungan bukit barisan masuk dalam pegunungan Sumatra yang tergabung dalam garis episenter sesar aktif gempa bumi (BAPELITBANG, 2017). Provinsi Bengkulu pada tahun 2007 gempa bumi yang berkekuatan 7,9 SR merusak lebih dari 27.000 rumah, sedangkan di tahun 2000 gempa bumi berkekuatan 7,3 SR mengakibatkan 28.203 rumah rusak ringan dan 12.990 rumah rusak berat, dan 3.250 rumah rusak total (SUPRIANI, 2009). Tipikal kerusakan pada bangunan rumah yang paling banyak adalah elemen dinding tembok dari batu bata. Hal tersebut karena anggapan bahwa sebagian besar rumah masyarakat berupa tembokan dapat meningkatkan status sosial dibanding rumah kayu. Namun bangunan hunian yang berbahan kayu di beberapa kabupaten di Provinsi Bengkulu justru masih tetap kokoh walaupun mengalami guncangan gempa bumi.

Gempa bumi yang memiliki getaran akan berpengaruh pada gaya dalam bangunan seperti gaya inersia, gaya guling, dan gaya torsi. Gaya tersebut akan menghasilkan reaksi fleksibilitas (kekakuan dan keliatan), redaman (penyerapan getaran untuk melawan gaya inersia), elastisitas dan duktilitas (kemampuan bangunan untuk melakukan deformasi plastis tanpa runtuh), dan hiperstatisan yang dibuat oleh unsur balok yang membentuk sendi plastis (Prihatmaji, 2007).

Berdasarkan hal tersebut adanya kemungkinan bahwa hunian dari kayu memiliki upaya antisipasi terutama hunian yang berada di wilayah dekat pusat gempa. Salah satu pemukiman yang banyak dijumpai hunian dari kayu yaitu pemukiman Suku Rejang di Desa Gunung Alam yang berada di perbatasan dengan kabupaten Bengkulu Utara (BAPELITBANG, 2017). Di tahun 2019, masih banyak dijumpai bangunan hunian dengan material kayu yang dihuni walaupun dewasa ini keberadaan hunian tua telah banyak yang dirubah bahkan dihancurkan dan dibangun kembali degan perwujudan rumah modern berbahan beton dan batu bata. Kondisi seperti ini sangat mengkhawatirkan dan memberikan dampak kepada jumlah hunian tua yang memiliki peran adaptif semakin berkurang jumlahnya. Jika tidak dilestarikan dan dikaji karakter bangunannya maka kemungkinan di masa depan, generasi muda Bengkulu tidak dapat mengenal identitas warisan budaya yang adaptif terhadap lingkungan.

Untuk menggali lebih dalam peran adaptif dari hunian Suku Rejang di daerah rawan gempa, maka penulis tertarik untuk melakukan penelitian yang mengkaji karakter bentuk hunian Suku Rejang sebagai hunian yang adaptif di daerah rawan gempa dengan studi kasus Desa Gunung Alam, kabupaten Lebong. Pemukiman Desa Gunung Alam dipilih menjadi lokasi kasus karena masih terdapat banyak hunian bermaterial kayu dan terletak di wilayah perbukitan yang memiliki tingkat kelembapan tinggi.

Penelitian ini bertujuan untuk mengidentifikasi bentuk hunian Suku Rejang dengan perannya sebagai bangunan yang adaptif terhadap lingkungan yang merupakan daerah rawan gempa. Sesuai dengan tujuan penelitian yang ingin diraih maka diharapkan penelitian ini bermanfaat untuk memperoleh pengetahuan mengenai bentuk hunian Suku Rejang di Kabupaten Lebong dan mengetahui peran hunian sebagai hunian yang adaptif di daerah rawan gempa.

\section{METODE}

Berdasarkan tujuan penelitian yaitu mengidentifikasi bentuk hunian Suku Rejang dengan perannya sebagai bangunan yang adaptif terhadap lingkungan yang merupakan daerah rawan gempa. Penelitian ini berupa penelitian deskriptif yang berusaha menggambarkan objek sesuai dengan keadaan apa adanya, yang mana peneliti tidak melakukan kontrol pada data penelitian (Ashadi et al., 2018). Metode yang digunakan adalah metode kualitatif yaitu mengekplorasi dan memahami bentuk hunian Suku Rejang yang memiliki peran sebagai bangunan adaptif di daerah rawan gempa.

Pencarian data dilakukan dengan teknik survei/ pengamatan langsung pada hunian Suku Rejang di Desa Gunung Alam dan mewawancara penghuni hunian tersebut, tetua Desa Gunung Alam, serta masyarakat sekitar untuk mngetahui prinsip-prinsip yang terkandung pada hunian tersebut. Untuk 
menganalisis karakter bentuk hunian, data yang diperoleh dilakukan dengan menguraikan dan membandingkan dengan teori sehingga temuan menghasilkan gambaran karakter hunian Suku Rejang yang memenuhi kaidah bangunan tahan gempa sehingga menjadi hunian yang adaptif terhadap lingkungan yang rawan gempa.

Penelitian dilakukan di Desa Gunung Alam, Kecamatan Pelabai, Kabupaten Lebong. Wilayah ini merupakan wilayah perbukitan yang dekat dengan perbatasan kabupaten Bengkulu Utara, kabupaten yang menjadi pusat gempa bumi di tahun 2007 termasuk dalam daerah rawan gempa. Pada pemukiman Desa Gunung Alam terdapat 54 hunian dengan sistem panggung. Dalam penentuan sampel ditentukan kriteria berdasarkan sistem rumah panggung, usia bangunan tertua dari setiap jenis bentuk hunian (>20-50 tahun). Sehingga jumlah hunian yang dipilih sebagai sampel yaitu 3 rumah dari 3 jenis bentuk hunian.

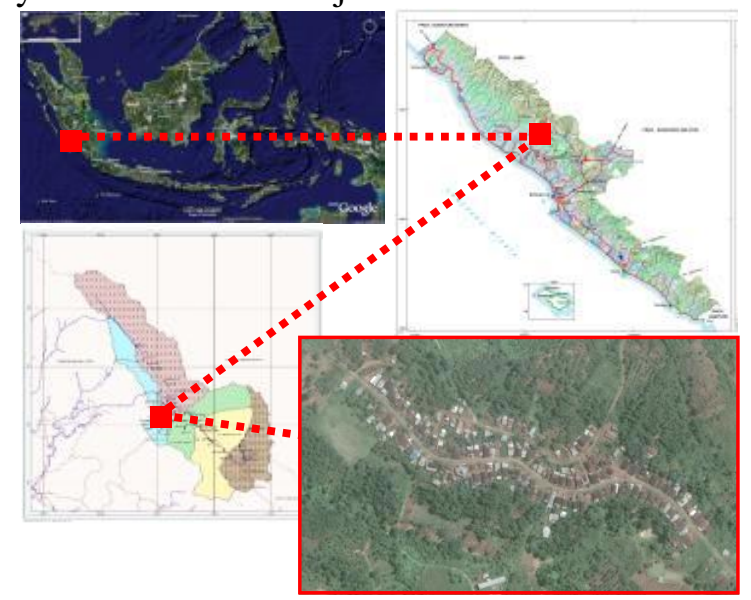

Gambar 1. Lokasi objek studi kasus di Desa Gunung Alam, Kabupaten Lebong

\section{HASIL DAN PEMBAHASAN}

\section{A. Arsitektur Vernakular dan Kerentanan Bencana Alam}

Hunian yang muncul di masyarakat merupakan hasil dari kebutuhan akan tempat tinggal dan menanggapi lingkungan dengan pengetahuan empiris yang diperoleh dari generasi ke generasi secara akumulatif melalui intuisi bagaimana mmanfaatkan sumber daya alam dengan sebaik-baiknya (Javier, Graca, \& Mariana, 2014). Hunian sebagai hasil karya manusia memiliki ketergantungan dan kesetimbangan antara eco system (sistem lingkungan hidup) yang memuat kondisi fisik fisiologis lingkungan dalam mencapai kenyamanan dan kepuasan fisik maupun biologis dan social system (sistem lingkungan sosial) (Pramono, 2007) sehingga sebagai tempat bernaung, mencitrakan kedudukan sosial (Cahyandari, 2012) dengan prioritas tiga hal yaitu kesempatan berkembang, keamanan, dan identitas/kekhasan.

Dalam perwujudan identitas karakteristik penghuni dan perkembangan sosial yang ada, maka kecenderungan membangun arsitektur hunian direpresentasikan terhadap tata cara secara fisik (sistem teknologi dan material kesesuaian alam serta iklim setempat) serta proses bermukim secara non fisik seperti kondisi budaya, perilaku masyarakat, dan agama (Rapoport, 1969). Arsitektur inilah yang tumbuh dan berkembang dari rakyat sehingga yang dinamakan arsitektur vernakular.

Arsitektur vernakular mencerminkan tradisi dan gaya hidup sekelompok komunitas, dan ikatannya dengan lingkungan alam. Sehingga memiliki kaitan erat dengan tempat, wilayah, dan sejarah komunitas tersebut. Penggunaan bahan material utama untuk konstruksi tersedia secara lokal dengan mengkondisikan prinsip ekonomi yaitu untuk menghemat energi dan upaya yang terlibat operasional, pengangkutan dan pembangunan. Perubahan fungsi dan bentuk pada hunian tradisional dapat mengakibatkan hilangnya makna maupun bentuk fisiknya sehingga pengembangan arsitektur vernakular yang dilakukan perlu berdasarkan pada arsitektur tradisional dengan pendekatan adaptif yang disesuaikan dengan perkembangan pandangan filosofis masa kini tanpa mengubah makna masa lalu (Tarigan, 2016).

Bangunan vernakular adalah wujud sebuah proses berkelanjutan yang ditandai dengan fleksibiltas dalam beradaptasi dan perubahan secara fungsional terhadap kebutuhan masyarakat. Cara-cara kelompok/ komunitas/masyarakat adalah reaksi terhadap kondisi krisis merupakan cerminan identitas budaya suatu komunitas dan hubungannya dengan alam sebagai adaptasi warisan vernakular yang dibangun dari memori 
kolektif dari peristiwa masa lalu yang dimanifestasikan dalam teknik konstruksi.

Kerentanan dari bencana alam gempa bumi dapat ditelusuri dari penyebab utama kerusakan dari gempa bumi melalui parameter konstruksi bangunan vernakular dalam menghadapi kerentanan gempa bumi sebagai berikut (Javier et al., 2014).

[1] konfigurasi antar bangunan dan ruang terbuka. Interaksi antar bangunan memiliki pengaruh yang signifikan dalam kinerja seismik struktur. Bangunan yang berdekatan dapat menyebabkan kerusakan pada titik-titik penghubung. Selain itu memberi pemisahan bangunan yang berdekatan dapat menjadi ruang keleluasaan dalam keadaan darurat.

[2] konfigurasi ruang yang sederhana, simetris, dan persegi panjang dengan rasio 1:2 yang banyak digunakan pada bangunan vernakular di daerah seismik. Penggunaan struktur lebih ringan pada atas lantai dasar seperti penggunaan material kayu. Pengurangan ketebalan dinding atau penggunaan bahan yang lebih ringan di lantai atas.

[3] penggunaan material dengan memahami karakter sifat material. Material memiliki pengaruh pada kinerja seismik pada banguan vernakular

[4] penggunaan lantai kayu untuk menghubungkan dan menyandingkan dindingdinding sebagai elemen horisontal yang menyerap guncangan gempa dengan sistem kerja diafragma.

[5] penggunaan atap yang ringan meningkatkan kinerja gempa.

[6] Sistem sambungan yang kuat mencegah gaya guling dari dinding secara eksternal

[7] jumlah bukaan yang tidak banyak dan simetris dalam tata letaknya distribusi kekakuan pada dinding dan kapasitas gaya geser yang rata.

[8] bentuk rangka bangunan yang saling terkait antara satu dengan bagian lainnya. Bentuk ini membuat bangunan kaku karena sistem rangka yang menyeluruh (Triyadi \& Harapan, 2008).

\section{B. Prinsip-prinsip konstruksi tahan gempa}

Berdasarkan SNI 03-1726-2002, Tata cara Perencanaan Ketahanan Gempa Untuk
Bangunan oleh Dinas Pekerjaan Umum tahun 2006, ada 3 prinsip dalam pembangunan rumah kayu tahan gempa yaitu: (1) Denah yang sederhana dan simetris, (2) Bahan bangunan harus seringan mungkin, (3) Sistem konstruksi yang memadai dalam mengurangi resiko gempa.

\section{Gambaran umum Suku Rejang dan Desa Gunung Alam}

Keberadaan hunian Suku Rejang banyak tersebar di kabupaten lainnya di provinsi Bengkulu. Hal ini disebabkan Suku Rejang merupakan salah satu suku tertua di provinsi Bengkulu yang mendominasi di beberapa kabupaten, salah satunya Kabupaten Lebong. Peradaban masyarakat Suku Rejang telah lebih maju dibanding masyarakat lainnya yang dapat dilihat dari adanya sistem petulai menandakan masyarakat Rejang sudah memiliki hukum adat yang dipatuhi oleh pendukungnya dan juga, ditandai adanya aksara kaganga.

Desa Gunung Alam yang berada di Kabupaten Lebong yang berjarak $\pm 9 \mathrm{~km}$ dari ibukota Muara Aman memiliki kondisi topografi bergelombang mencirikan bahwa Desa Gunung Alam berada pada bentang alam pegunungan. Kondisi air tanah wilayah Desa Gunung Alam air di permukaan tanah mengalir sangat cepat, kondisi ini hampir semua air hujan di alirkan dengan kecepatan yang relatif tinggi di permukaan tanah sehingga selain rawan bencana gempa bumi, juga rawan longsor dahulu kalanya. Permukiman Desa Gunung Alam merupakan salah satu permukiman tertua Suku Rejang, memiliki kekayaan adat istiadat dan masih mempertahankan arsitektur rumah adat Suku Rejang. Hal ini yang menjadi salah satu alasan pemilihan lokasi penelitian di desa Gunung Alam. Selain itu, lokasi penelitian berada di Desa Gunung Alam Kecamatan Pelabai Kabupaten Lebong berada di wilayah perbukitan.

Dari 54 hunian yang ada, sampel penelitian dipilih berdasarkan kriteria yaitu sistem rumah panggung, usia bangunan tertua dari setiap jenis bentuk hunian ( $>50$ tahun). Sehingga terdapat 3 rumah dari 3 jenis bentuk hunian yang tersebar pada gambar 2 . 


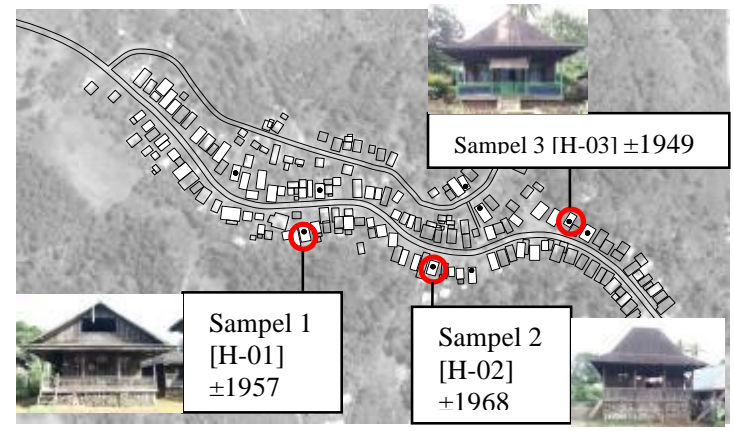

Gambar 2. Letak sampel hunian yang dipilih

\section{Karakter Bentuk Hunian Suku Rejang}

Secara garis besar hunian Suku Rejang di Desa Gunung alam memiliki ciri yaitu:

1) Bangunan panggung

Hunian Suku Rejang berbentuk panggung dengan lantainya lebih tinggi $\pm 0,6-1,40$ meter dari permukaan tanah. Struktur utama bangunan menggunakan kayu. Bangunan menggunakan tiang penopang kayu dan batu yang diletakkan di atas tanah.

\section{2) Pola tata massa hunian}

Desa Gunung Alam merupakan desa yang terletak di bentang alam perbukitan yang awalnya dikelilingi oleh hutan. Bentuk pola pemukiman yang memiliki orientasi massa dan bukaan langsung ke arah akses utama meningkatkan pengawasan terhadap hunian lain di sekitarnya. Filosofi bangunan menghadap ke jalan dengan tujuan agar dapat melihat musuh lebih cepat. Pola tatanan hunian yang ada di desa Gunung Alam umumnya terbentuk secara alami mengikuti akses jalan dan kontur tanah. Hunian di Desa Gunung Alam memiliki ruang terbuka privat di depan hunian yang difungsikan sebagai area menjemur hasil panen. Jarak antar hunian antara 2,5- 3 meter.

3) Denah dan massa hunian

Sistem pembagian ruang di hunian berdasarkan aspek fungsi, ruang dibagi menjadi tujuh ruang yaitu berendo, danea, senigo, dopoa, ga-ang, loteng seperti pada tabel 1. Pembagian ruang hunian vernakular serupa pada rumah tradisional asli Suku Rejang yang disebut dengan Umeak Potong Jang yang berarti rumah buatan Rejang. Ruang dibagi menjadi empat kategori yaitu publik, semi publik, privat, dan servis. Ruang publik diwakili oleh berendo (ruang depan/teras publik yang difungsikan untuk menerima tamu yang belum dikenal). Ruang semi publik diwakili Danea (ruang bersama untuk melakukan kegiatan hajat dan menerima tamu dari kerabat/orang yang dikenal). Ruang privat diwakili ruang senigo (ruang keluarga yang juga difungsikan sebagai ruang makan), pedukuak (ruang kamar), dan loteng yang difungsikan untuk menjemur hasil panen seperti kopi dan padi. Ruang servis diwakili ruang dopoa (dapur) dan ga-ang (area basah/ dapur kotor). Pembagian ruang pada hunian telah mengalami penyesuaian kebutuhan dan pola kehidupan seperti perubahan fungsi ruang kolong rumah untuk menyimpan ternak dan ruang berkumpul, saat ini menjadi ruang menyimpan kayu bakar. Ruang loteng yang berfungsi menyimpan/menjemur hasil panen dahulunya untuk kamar bagi anak perempuan yang belum menikah. Perubahan lainnya adalah adanya massa tambahan berupa kamar mandi dan dapur Sehingga terbentuk massa bangunan yang asli dan tambahan, massa bangunan asli ditandai dengan blok merah dan massa bangunan tambahan ditandai dengan blok warna ungu.

Tabel 1. Denah dan bentuk massa hunian Suku Rejang

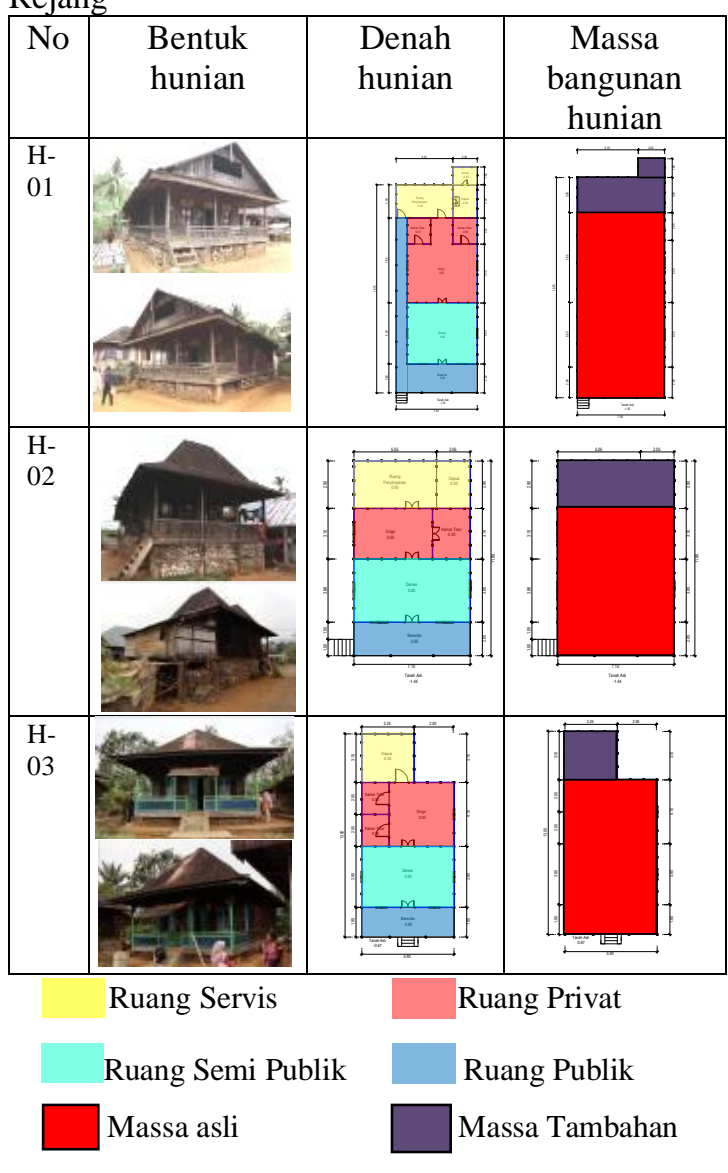


Ukuran denah rumah massa berbentuk persegi panjang dan berukuran $7,30 \mathrm{~m} \times 15,75 \mathrm{~m}[\mathrm{H}-$ 01]; 7,10 m x 9,00 m [H-02]; 5,90 m x10 m [H-3].

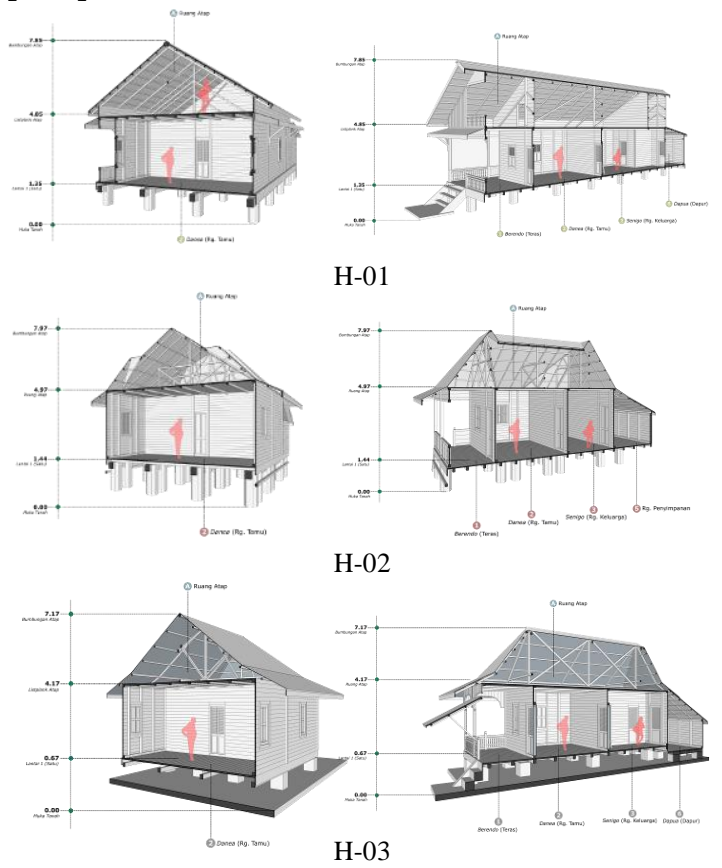

Gambar 3. Potongan ragam bentuk hunian

Bentuk massa hunian yang ada di Desa Gunung Alam memiliki tiga jenis yang dibedakan dengan bentuk atapnya yaitu atap pelana [H-01], atap limas [H-02], atap perisai [H-03] dengan rangka bangunan membentuk box balok dengan rasio ketinggian antara struktur bawah, struktur tengah, dan struktur atas 1,5:3:3 seperti yang terlihat pada gambar 3. Kemiringan atap $\geq 30^{\circ}$ dan teritisan dengan kemiringan $\pm 15^{0}$ berukuran lebar $150 \mathrm{~cm}$. sesuai dengan kemiringan atap yang tanggap iklim tropis dengan curah hujannya tinggi. Fungsi utama kemiringan atap adalah mengalirkan air hujan sebelum merembes ke dalam bangunan. Hal tersebut dilihat dari bentuk sudut kemiringan bangunan yang tinggi selain aspek iklim tropis dan kelembapan udara yang tinggi pada Desa Gunung Alam.

4) Sistem struktur dan material

Gambaran material dan struktur umum hunian Suku Rejang yang telah diuraikan sebelumnya menggunakan kayu sebagai rangka struktur bangunan (pondasi, kolom, balok, rangka kuda-kuda, dan lain-lain) sehingga hunian Suku Rejang cenderung memiliki bahan bangunan yang ringan. Struktur hunian terdiri dari struktur bawah, struktur tengah, dan struktur atas. Oleh karena itu perlu dikaji material pada tiap-tiap struktur hunian. Adapun klasifikasi struktur hunian Suku Rejang di Desa Gunung Alam adalah berikut.

a) Struktur Bawah

Pada hunian Suku Rejang struktur bawah adalah bagian struktur yang memiliki beban paling besar karena menumpu beban dari struktur tengah dan atas.
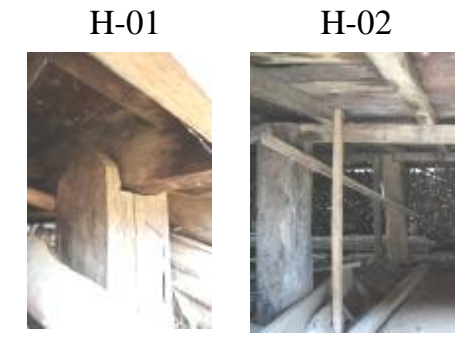

H-03

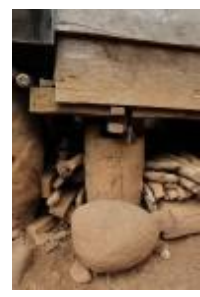

Gambar 4. Struktur bawah hunian

Pada gambar 4, struktur bawah terdapat empat komponen yaitu [1] umpak batu tebal $\pm 12 \mathrm{~cm}$ dengan dimensi $60 \times 60 \mathrm{~cm}$ [2] tiang penopang dengan diameter 20-40 $\mathrm{cm}$; [3] balok sloof ukuran 20x20 cm [4] balok pembagi ukuran $15 \mathrm{~cm} \quad \mathrm{x} \quad 15$ $\mathrm{cm}$.Seluruh material hunian menggunakan material kayu setempat seperti Kayu medang kuning, kayu balam, kayu matiak abang, bambu Serik, Bambu Dabuk, dan Bambu Menyan yang banyak dijumpai di sekitar kabupaten Lebong. Kayu-kayu yang dipilih memiliki kekuatan kayu kelas I dan keawetan kayu kelas II.

b) Struktur Tengah

Merupakan bagian fungsional karena adanya aktivitas manusia dan sirkulasi yang terjadi di dalamnya. Pada struktur tengah terdapat beban hidup (manusia atau benda bergerak) dan beban mati (perabot). Pada gambar 5, struktur tengah terdiri dari lima komponen, [1] balok lantai berukuran $15 \mathrm{~cm} \times 15 \mathrm{~cm}$ dengan jarak $75 \mathrm{~cm} \mathrm{[2]}$ papan lantai dengan tebal $2 \mathrm{~cm} \mathrm{[3]} \mathrm{tiang}$ dinding ukuran $10 \mathrm{~cm} \times 10 \mathrm{~cm}$ dengan jarak antar tiang $100 \mathrm{~cm}$ atau terletak mengapit bukaan jendela dan pintu [4] balok pengapit dinding atas dan dinding bawah ukuran 10 $\mathrm{cm} \times 10 \mathrm{~cm} \mathrm{[5]} \mathrm{papan} \mathrm{dinding} \mathrm{dengan} \mathrm{tebal}$ $2 \mathrm{~cm}$. 


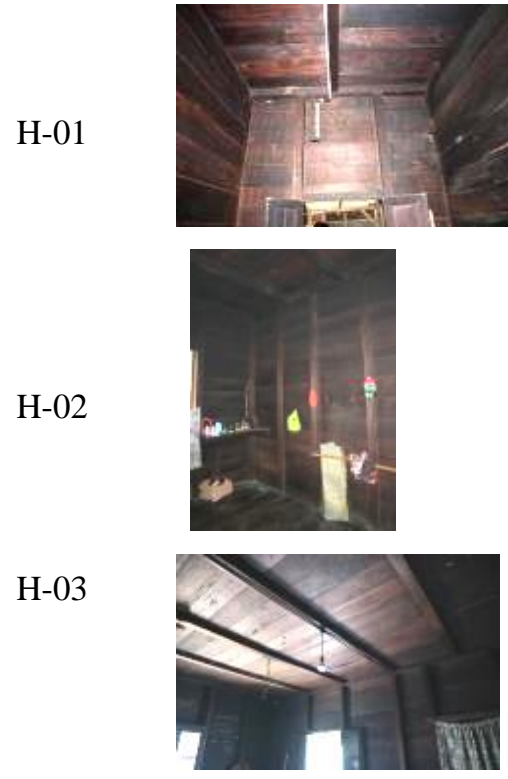

Gambar 5. Struktur tengah hunian

\section{c) Struktur Atas}

Pada gambar 6, langit-langit bangunan tidak terdapat plafon namun terdapat papan lantai dari lantai atas yaitu ruang loteng yang digunakan untuk menyimpan dan atau menjemur hasil panen.
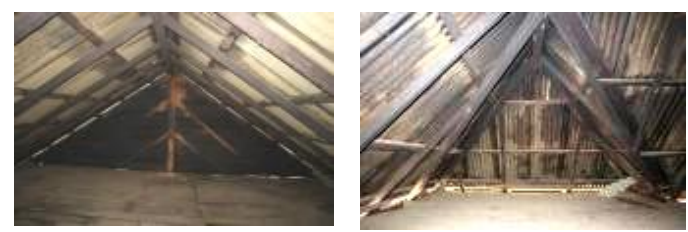

Gambar 6. Ruang loteng pada hunian vernakular

Penutup atap menggunakan seng dengan rangka kuda-kudanya menggunakan paku. Struktur atas merupakan bagian struktur yang lebih ringan dibanding struktur dibawahnya. Kuda-kuda atap menggunakan material kayu berdimensi $10 \mathrm{~cm} \times 12 \mathrm{~cm}$ dengan bentang kuda-kuda $\pm 8,00$ meter berjarak $\pm 1,00$ meter.

\section{5) Sistem sambungan}

Hunian Suku Rejang memiliki detail sambungan karena sistem konstruksi hunian bersifat knockdown. Pada konstruksi bagian struktur bawah terdapat coakan pada tiang penopang dengan balok sloof. Sambungan takik antar kayu ditumpu diatas tiang penopang. Pada struktur tengah, dinding disusun secara horizontal dengan sistem sambungan lidah dan dijepit pada kolom maupun kusen bangunan.

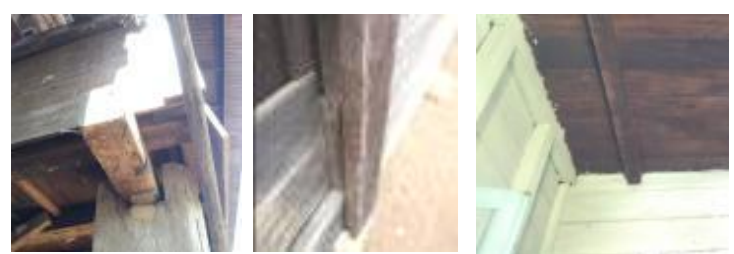

Gambar 7. (kiri atas) Coakan pada kolom-balok sloof ;(kanan atas) sambungan lidah pada dinding; (bawah) sambungan jepit antara kolom-dinding

6) Sistem bukaan

Bukaan pada hunian berjumlah enam buah dengan tata letak yang simetris. Bukaan memiliki lebar $75 \mathrm{~cm}$ dan tinggi $160 \mathrm{~cm}$. Luasan bukaan jendela berukuran $1,20 \mathrm{~m}^{2}$. Bentuk bukaan memiliki 4 daun jendela sehingga membentuk dua lapis bukaan, dua daun jendela menghadap keluar dengan material kayu berbentuk jalusi dan dua daun jendela bermaterial kombinasi kayu dan kaca seperti pada gambar 8 .
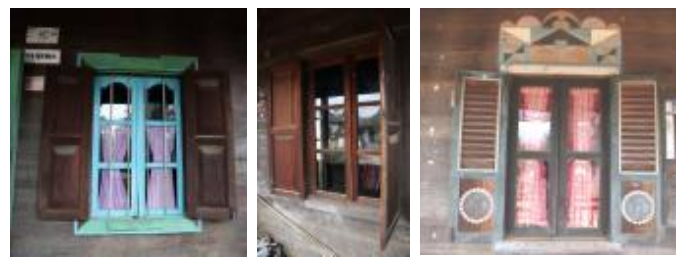

Gambar 8. Bentuk bukaan pada hunian vernakular

7) Sistem membangun dan memelihara hunian

Budaya dalam membangun hunian Suku Rejang di Desa Gunung Alam yang dikenal tradisi betije'. Betije' merupakan prosesi tegak bubung membangun rumah. Tradisi betije' dilakukan seseorang membangun rumah. Setelah tradisi betije', proses membangun rumah dilakukan secara bergotong royong hingga struktur rumah sudah terbangun. Selanjutnya pembangunan rumah dilaksanakan sendiri oleh pemilik rumah maupun dibantu oleh saudara atau mengupah tukang. Penggunaan material kayu yang digunakan dalam konstruksi hunian pun menggunakan aturan adat apabila mengarah ke kepala air atau mengarah mata air, atau menusuk ke leko' itu berarti kayu tidak boleh diambil karena tandanya celaka dalam arti orang Rejang. apabila kayu yang kita ambil tumbangnya mengarah ke desa atau kampung. Maka hal tersebut sebagai tanda yang baik untuk membangun rumah. Pemeliharaan warna 
bangunan hunian dahulunya menggunakan warna alami seperti coklat menggunakan tanah dari kulit siput yang dibakar. Selain itu mewarnai bangunan rumah dengan air jeruk nipis dan arang lampu, selain menghasilkan warna alami, warna yang dihasilkan membentuk keawetan bagi bangunan. Pemeliharaanhunian terhadap rayap dilakukan dengan proses pemasangan balok loteng atau ring baloknya ditutup dengan seng diatas alasalasnya. Balok-balok kayu yang menghubungkan bagian atas dengan hunian dinamakan peran.

\section{Peran Hunian Sebagai Bangunan Adaptif di Daerah Rawan Gempa}

1) Konfigurasi bangunan hunian

Bentuk massa hunian Suku Rejang berupa bentuk persegi panjang dengan ukuran perbandingan 1:2 antara lebar dan panjang bangunannya. Rasio perbandingan ini sesuai prinsip bangunan tahan gempa SNI 03-17262002 bahwa denah sederhana dan simetris dapat mengurangi resiko saat gempa bumi (Badan Standardisasi Nasional Indonesia, 2002). Bangunan yang memiliki bentuk yang sederhana dan simetris mempengaruhi kinerja bangunan saat gempa apabila bangunan sederhana maka ketika ada gaya horizontal akan terdistribusi secara merata dan efek torsi lebih rendah sehingga mengurangi resiko kerusakan atau bangunan patah.

Tata letak bukaan hunian Suku Rejang di Desa Gunung Alam yang simetris dengan sumbu denah bangunan memiliki pengaruh distribusi gaya geser gempa yang terjadi pada sisi bukaan sehingga lebih adaptif terhadap gempa (Andinna, Wisnumurti, \& SMD, 2018). Letak bukaan yang tidak berkelompok pada hunian Suku Rejang dalam konteks mitigasi bencana terutama gempa bumi, hunian vernakular yang memiliki perletakan bukaan yang tidak mengelompok akan menjadikan keseimbangan massa (Kamurahan, 2018).

Penggunaan dinding kayu menghasilkan beban 15 kali beban lebih kecil dibanding dinding bata (Prihatmaji, Pramono, \& Nugroho, 2013). Adanya balok pengapit pada hunian berfungsi mengkakukan hubungan antara tiang kolom dan balok atas. Antar kolom juga disatukan dengan rangka dinding (tempat menempel dinding papan atau anyaman bambu) dimana hal ini menambah kekakuan keseluruhan rangka bangunan. Dindingdinding penyekat ruangan (partisi) bentuknya atau susunannya sangat teratur dan selalu dikaitkan dengan kolom. Selain adanya ikatan antara balok dan kolom pada bidang dinding bangunan juga ada ikatan di dalam bangunan, yaitu balok bawah dan atas dinding partisi yang menghubungkan antar kolom. Gubahan struktur bangunan yang demikian sangat kaku dan membentuk kesatuan struktur yang dapat mengantisipasi beban gempa.

Penggunaan material kayu untuk dinding dan atap menjadi salah satu cara pengurangan beban yang ada pada hunian Suku Rejang. Hal ini yang membuat hunian Suku Rejang memiliki tingkat keseimbangan yang baik antara gaya yang timbul dengan gaya yang disalurkan ini seperti pada gambar 9 .

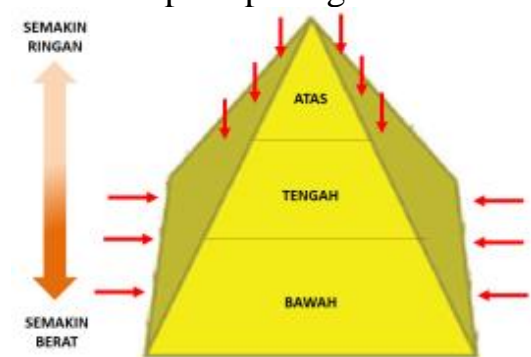

Gambar 9. Keseimbangan struktur hunian Suku Rejang

Perbandingan rasio ketinggian pada struktur bawah, struktur tengah dan struktur atas dengan rasio 1,5: 3: 3. Dapat ditarik kesimpulan bahwa material yang berat terdapat di struktur bawah dan material ringan terdapat di struktur atas secara seimbang. Arah gaya terbagi menjadi dua yaitu gaya horizontal dan gaya vertikal (Rinaldi, Purwantiasning, \& Nur'aini, 2015). Keseimbangan ini mempengaruhi pengurangan resiko kerusakan tiap struktur pada saat gempa bumi terjadi.

\section{2) Sistem konstruksi}

Gempa bumi menggetarkan struktur bawah (pondasi bangunan) melalui tanah, getaran tersebut tidak beraturan dan merambat ke atas melalui komponen vertikal (struktur tengah), dan disebarkan secara horizontal melalui lantai/atap. Adapun sistem penyaluran gaya dan sistem reduksi gaya pada hunian Suku Rejang sebagai hunian yang adaptif di daerah rawan gempa adalah sebagai berikut. 
a) Sistem penyalur gaya

Setiap struktur memiliki peran sebagai penahan gaya. Gaya terbagi menjadi dua yaitu gaya internal dari beban mati dan beban hidup serta gaya eksternal meliputi beban angin dan beban gempa (Rinaldi et al., 2015). Sistem penyaluran gaya pada hunian Suku Rejang dapat dilihat pada gambar 9-12.

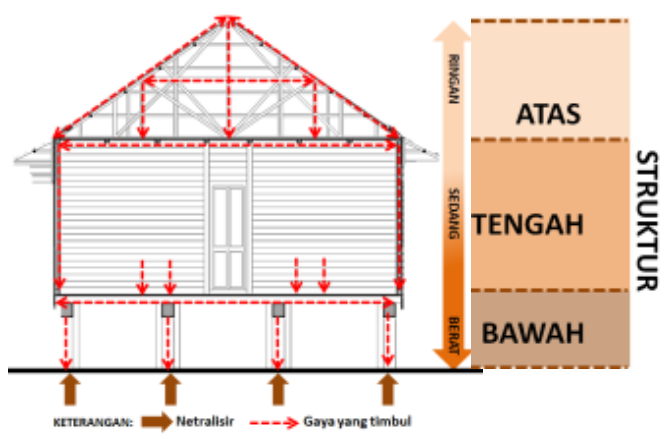

Gambar 11. Penyaluran beban mati pada hunian

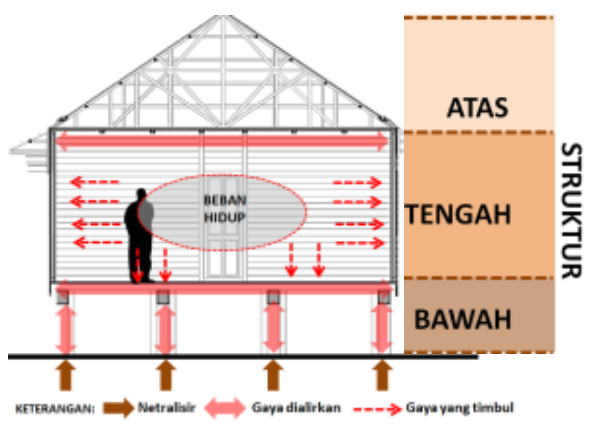

Gambar 12. Penyaluran beban hidup pada hunian

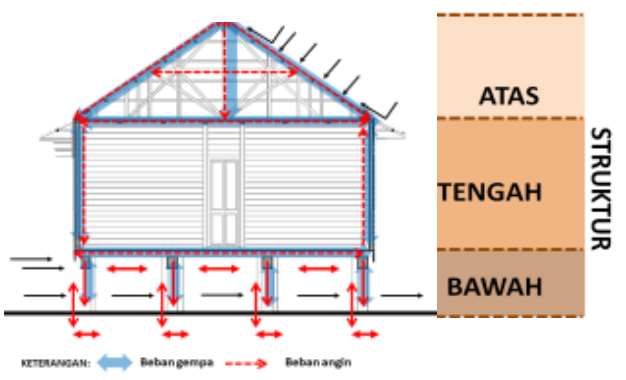

Gambar 13. Penyaluran beban gempa dan angin pada hunian

Gaya horizontal yang bersifat elastis agar tersalurkan pada jalur lintasan gaya yang dapat menahan gaya horisontal. Dinding bangunan yang berupa papan ditempelkan pada rangka dinding selain digunakan sebagai tempat menempel dinding juga sebagai rangka pintu dan jendela. Susunan dan dimensi rangka dinding secara tidak sengaja menjadi kesatuan rangka bangunan dan memperkuat rangka bangunan secara keseluruhan terutama terhadap getaran gempa.

b) Sistem reduksi gaya

Struktur bawah sebagai pondasi bangunan dibuat dengan bahan yang berat yang bertujuan sebagai penumpu dan penyeimbang dari struktur diatasnya dan menyalurkan beban-beban tersebut ke tanah. Pada hunian Suku Rejang ini gaya yang ditimbulkan oleh gempa di reduksi oleh struktur bawah meliputi umpak batu berupa pecahan batu atau batu bulat atau beton (pada hunian vernakular yang usianya lebih muda). Umpak batu diletakkan diatas tanah dan menopang tiang penopang dan berfungsi sebagai pondasi. Selain itu, adanya balok sloof sebagai tumpuan rol yang menerima gaya tegak lurus, dan tidak mampu menahan momen berfungsi untuk mengakomodir pemuaian pada konstruksi sehingga konstruksi tidak rusak. Adapun dasar perilaku umpak dan balok sloof pada hunian Suku Rejang dalam mereduksi gaya dapat dilihat pada gambar 13.

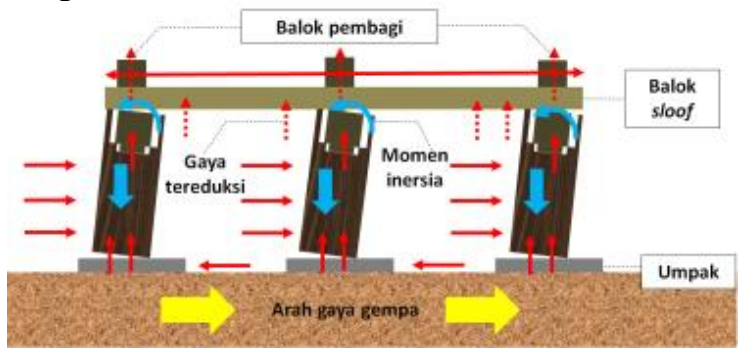

Gambar 15. Dasar perilaku dan hubungan umpak dan balok sloof

Ketika gempa, jalur lintasan gaya bersifat vertikal namun gaya inersia tiap struktur bersifat horisontal. Hal ini bertujuan untuk menciptakan keseimbangan pada bangunan.

\section{KESIMPULAN}

Berdasarkan pembahasan yang telah diuraikan, dapat diperoleh kesimpulan bahwa antara bencana alam dengan struktur bangunan dan struktur bangunan dengan bentuk tampilan bangunan memiliki keterkaitan. Dari sudut pandang arsitektur, bahwa perilaku bencana alam dapat mempengaruhi bentuk dan 
tampilan bangunan sehingga karakter bentuk bangunan saling terkait dengan ruang, susunan ruang, dan struktur. Keterkaitan konfigurasi bangunan (bentuk, ukuran, sifat, tata letak elemen) menentukan pengaruh terhadap respon bangunan yang pada akhirnya menentukan komponen struktural. Keadaptifan hunian Suku Rejang sebagai hunian di daerah rawan bencana gempa telah diterapkan bentuk rumah panggung yang memiliki rasio perbandingan antara lebar dan panjang bangunan 1:2, susunan ruang yang ada terbentuk mengikuti titik tiang penopang dibawahnya sehingga membentuk denah sederhana dan simetris menggunakan material utama kayu lokal setempat. Rasio perbandingan ketinggian tiap struktur 1,5: 3: 3 itu artinya hunian Suku Rejang memiliki ketinggian yang seimbang antara tinggi atap dengan tinggi dinding. Namun, penggunaan paku telah banyak ditemukan di dalam hunian dan penambahan ruang yang membentuk massa baru dibelakang massa asli hunian dengan material bata menjadi resiko apabila terjadi gempa dikemudian hari. Walaupun demikian, bentuk hunian Suku Rejang di Desa Gunung Alam ada saat ini masih kokoh untuk dihuni oleh Suku Rejang.

\section{UCAPAN TERIMAKASIH}

Penelitian ini dilakukan dengan dukungan pendanaan dari anggaran PNBP Universitas Bengkulu tahun 2019 yang telah memberikan kesempatan dan untuk melaksanakan kegiatan penelitian 'Identifikasi karakteristik Bentuk dan Tata Ruang Rumah Vernakular Rejang Dalam Konteks Mitigasi Bencana di Desa Gunung Alam, Kabupaten Lebong'.

\section{REFERENSI}

Andinna, D. H., Wisnumurti, \& Smd, A. (2018). Pengaruh Letak Bukaan Pada Bangunan Rumah Satu Lantai Dalam Menahan Beban Gempa di Kota Malang. Jurnal Mahasiswa Jurusan Teknik Sipil, 1(2), hal.1-15.

Ashadi, A., Jakarta, U. M., Kuffa, A., Jakarta, U. M., Dewi, R., \& Jakarta, U. M. (2018). Penerapan Metode Kuantitatif Dan Kualitatif Dalam Penelitian Arsitektur (1st Ed.). Jakarta, Indonesia: Program Studi Arsitektur Fakultas Teknik Universitas Muhammadiyah Jakarta .

Badan Standardisasi Nasional Indonesia. (2002). Standar Perencanaan Ketahanan Gempa
Untuk Struktur Bangunan Gedung. SNI-17262002, 7798393(April).

Bapelitbang. (2017). Peta Sumber Dan Bahaya Gempa Indonesia Tahun 2017 (Edisi 1; PUPR, Ed.). Bandung, Indonesia: Pusat Penelitian dan Pengembangan Perumahan Dan Permukiman.

Cahyandari, G. O. I. (2012). Tata Ruang dan Elemen Arsitektur Pada Rumah Jawa di Yogyakarta Sebagai Wujud Kategori Pola Aktivitas Dalam Rumah Tangga. Jurnal Arsitektur Komposisi, 10(2), hal. 103-118.

Javier, O., Graca, V., \& Mariana, C. (2014). An Overview Of Seismic Strengthening Techniques Traditionally Applied In Vernacular Architecture. 9th International Masonry Conference 2014 In Guimarães, hal. 1-12. Guimarães, Portugal: Universidade Do Minho Escola De Engenharia.

Kamurahan, S. R. (2018). Struktur dan Konstruksi Rumah Panggung Masyarakat Kampung Jawa Tondano (Jaton) di Tinjau Dari PrinsipPrinsip Bangunan Tahan Gempa. Media Matrasain, 15(1), hal.1-8.

Pramono, Y. S. (2007). Konsep Tentang Home Dan Identitas Arsitektur Hunian. Jurnal Spectra, 1(1), hal. 1-7.

Prihatmaji, Y. P. (2007). Perilaku Rumah Tradisional Jawa "Joglo" Terhadap Gempa. Dimensi Teknik Arsitektur, 35(1), hal. 1-12.

Prihatmaji, Y. P., Pramono, W. B., \& Nugroho, C. A. (2013). Penyuluhan Bangunan Rumah Tahan Gempa Sebagai Optimalisasi Mitigasi Gempa Bumi. Jurnal Inovasi dan Kewirausahaan, 2(3), hal. 233-239.

Rapoport, A. (1969). House, Form, And Culture. USA: Prentice-Hall.

Rinaldi, Z., Purwantiasning, A. W., \& Nur'aini, R. D. (2015). Analisa Konstruksi Tahan Gempa Rumah Tradisional Suku Besemah di Kota Pagaralam Sumatera Selatan. Seminar Nasional Sains dan Teknologi 2015, Fakultas Teknik Universitas Muhammadiyah Jakarta, (November), hal. 1-10. Jakarta, Indonesia: Fakultas Teknik Universitas Muhammadiyah Jakarta.

Supriani, F. (2009). Studi Mitigasi Gempa Di Bengkulu Dengan Membangun Rumah Tahan Gempa. Jurnal Teknik Sipil - Inersia, 1(1), hal. 7-16.

Tarigan, R. (2016). Arsitektur Vernakular Berbasis Arsitektur Tradisional: Menuju Arsitektur Lokal Yang Berkelanjutan. Tesa Arsitektur, 14(1), hal. 23-32.

Triyadi, S., \& Harapan, A. (2008). Kearifan Lokal Rumah Vernakular di Jawa Barat Bagian Selatan Dalam Merespon Gempa. Jurnal Sains dan Teknologi Emas, 18(2), hal. 123-134. 